\title{
KINERJA RUMAH SAKIT UMUM DAERAH KABUPATEN BULELENG DALAM PELAYANAN TERHADAP PASIEN JKBM
}

\author{
I Dewa Gd Bayu Ari Amerta, Made Sri Mariani, Kadek Peni Ariani, Putri Ayu \\ Lestari, Ketut Putri Ariani
}

Jurusan Akuntansi, Universitas Pendidkan Ganesha, Singaraja, Buleleng, Bali

\begin{abstract}
Abstrak
Penelitian ini bertujuan untuk mengungkap bagaimana sejarah dan Profil RSUD Buleleng, bagaimana sistem pemberlakuan JKBM di RSUD Buleleng, apakah tujuan dibentuknya JKBM sudah sesuai dengan realita yang ada di masyarakat, bagaimana respon dan tanggapan masyarakat dengan adanya JKBM, Apakah kualitas pelayanan RSUD Buleleng terhadap pasien JKBM sudah baik, serta mengapa RS Swasta di Buleleng menghentikan program JKBM. Penelitian ini dilakukan melalui teknik wawancara dan dokumentasi. Hasil penelitian menunjukkan bahwa Rumah Sakit Umum Daerah Kabupaten Buleleng memiliki Isue-Isue Strategis (Strategic Issues) yang memiliki dokter spesialis, bangunan RS baru dan berlokasi strategis, mindset masyarakat pengguna semakin matang dan dewasa dan kontrak dengan berbagai perusahaan swasta, BUMN dan customer maintain belum terpupuk dengan baik.
\end{abstract}

Kata kunci: Kinerja rumah sakit; JKBM; Kabupaten Buleleng

\section{Abstract}

This study aims to uncover how the history and profile of Buleleng Regional Hospital, how the JKBM implementation system in Buleleng Regional Hospital, whether the purpose of establishing $J K B M$ is in accordance with the reality in the community, how the response and response of the community with the existence of JKBM, What is the quality of Buleleng Hospital services to JKBM patients it's good, and why the Private Hospital in Buleleng stopped the JKBM program. This research was conducted through interview and documentation techniques. The results showed that the Buleleng Regency Regional General Hospital has Strategic Issues that have specialist doctors, new and strategically located hospital buildings, the mindset of the user community is more mature and mature and contracts with various private companies, SOEs and customer maintainers have not well nurtured.

Keywords: Hospital performance; JKBM; Buleleng Regency

\section{Pendahuluan}

Kesehatan adalah hak asasi dan sekaligus merupakan investasi untuk keberhasilan pembangunan bangsa. Untuk itu diselenggarakan pembangunan kesehatan secara menyeluruh dan berkesinambungan, dengan tujuan guna meningkatkan kesadaran, kemauan dan kemampuan hidup sehat bagi setiap orang agar terwujud derajat kesehatan masyarakat setinggi-tingginya. Untuk mencapai hal tersebut, Visi Departemen Kesehatan RI adalah "Masyarakat yang mandiri untuk hidup sehat" dengan misi : " Membuat masyarakat sehat "yang akan dapat tercapai dengan salah satu strateginya adalah meningkatkan pembiayaan kesehatan.

Ada 4 pilar utama yang mempengaruhi derajat kesehatan masyarakat yakni faktor genetik, faktor lingkungan, faktor prilaku, serta Aksessibilitas pelayanan kesehatan masyarakat. Oleh karena itu intervensi program harus fokus kepada akar masalah kesehatan tersebut diatas, khususnya menggarap hulunya yakni menciptakan Lingkungan Sehat dan memberdayakan masyarakat untuk Berprilaku Hidup Bersih dan Sehat, sejalan dengan upaya membenahi Aksessibilitas pelayanan kesehatan yang terjangkau oleh masyarakat.

Disamping berpengaruh terhadap Lingkungan dan Prilaku, kemiskinan juga secara nyata mempengaruhi Aksessibilitas Pelayanan Kesehatan, khususnya menyangkut biaya pelayanan kesehatan yang semakin mahal sehingga tidak terjangkau kebanyakan 
masyarakat. Terlebih lagi dengan sistem pembayaran yang ditanggung sendiri oleh masyarakat (Out of Pocket), kebanyakan masyarakat tidak sanggup membayar ketika mereka jatuh sakit, apalagi kalau penyakitnya berat dan perlu tindakan operasi, atau menderita penyakit kronis yang memerlukan perawatan jangka panjang seperti Hemodialisa, penyakit jantung, kanker, dll. Kalau kondisi ini dibiarkan terus berjalan, tentu akan berdampak pada derajat kesehatan masyarakat yang pada akhirnya bermuara kepada rendahnya Indek Pembangunan Manusia (IPM) masyarakat Bali.

Sekitar 72,12 \% dari penduduk Bali belum memiliki Jaminan Pemeliharaan Kesehatan yang senantiasa akan bermasalah ketika mereka jatuh sakit. Bahkan mereka yang sudah tercakup asuransipun masih ada kendala, karena sebagian Asuransi yang dikembangkan Pemerintah Kabupaten, portabilitasnya masih terbatas sampai tingkat pelayanan dasar atau tingkat rujukan lokal (RS kabupaten setempat), sehingga akan tetap bermasalah ketika harus ketingkat Provinsi atau Pusat.

Berdasarkan hal tersebut diatas, Pemerintah Provinsi Bali (Gubernur dan Bupati/Walikota) mengambil kebijakan untuk menaungi masyarakat dengan pelayanan kesehatan melalui program Jaminan Kesehatan Bali Mandara (JKBM) untuk seluruh Masyarakat Bali. JKBM adalah program jaminan kesehatan yang diluncurkan Pemerintah Provinsi Bali. Program ini di peruntukan bagi masyarakat Bali yang belum memiliki asuransi Askes, Jamsostek, Asabri, Askeskin atau Jamkesmas atau Jaminan kesehatan lainnya. Tujuan dari program ini adalah untuk meningkatkan akses dan mutu pelayanan kesehatan masyarakat. Sejak pertama kali diluncurkan tahun 2010 lalu program ini oleh masyarakat Bali. Banyak masyarakat yang merasa sangat terbantu dengan adanya program ini khususnya bagi mereka yang tidak mampu. Memang sudah ada program Jamkesmas dari pemerintah pusat namun tidak semua orang mendapatkannya. JKBM sangat terasa manfaatnya untuk biaya pengobatan terutama untuk penyakit kronis yang membutuhkan biaya besar. Dengan program ini masyarakat banyak terbantu dan merasakan manfaat yang luar biasa dari program ini. Program jaminan kesehatan ini bisa berlaku di seluruh Bali mulai dari puskesmas, Rumah Sakit Daerah dan Rumah Sakit Pusat Sanglah. Alur pelayanannya memang harus dari puskesmas kalau tidak bisa ditangani dirujuk ke rumah sakit daerah lalu ke rumah sakit pusat sanglah. Menjaga kesehatan memang penting namun saat kita sudah terlanjur menderita sebuah penyakit tentu saja yang paling pertama menjadi masalah adalah dana berobat. Semuanya akan menjadi lebih baik andai saja ada dana untuk berobat. Bagi mereka yang hidup pas-pasan tentu sangat berterimakasih dengan program ini. Masyarakat berharap program jaminan kesehatan ini tetap berlanjut demi meningkatkan beban masyarakat dan membantu orang yang sedang mencari kesembuhan. Adapun tujuan khusus pelayanan JKBM diantanya adalah sebagai berikut:

1. Meningkatkan cakupan masyarakat Bali yang mendapatkan pelayanan kesehatan.

2. Meningkakan kualitas pelayanan kesehatan bagi masyarkat Bali.

3. Pengelolaan keuangan yang transparan dan akuntabel.

Berdasarkan tujuan JKBM di atas tidak sesuai dengan realita yang ada di Rumah Sakit

Umum Daerah Buleleng. Banyaknya keluhan dari masyarakat terutama masyarakat menengah ke bawah, bahwa pelayanan bagi pengguna JKBM seharusnya sama dengan pelayanan pasien non JKBM dan tidak ada diskriminatif. Namun pada kenyataannya banyak sekali keluhan seperti kurang ramah dan kurang sigapnya petugas rumah sakit dalam memberikan pelayanan serta masih adanya sikap diskriminatif terhadap pasien JKBM rawat inap yang mayoritas dari keluarga kurang mampu di Rumah Sakit Umum Daerah Buleleng (RSUD).

Pelaksanaan JKBM di RSUD Buleleng akhir-akhir ini terkesan kurang memuaskan. Pasalnya, pelayanan JKBM di RSUD Buleleng selalu terlambat yang disebabkan kurang sigapnya petugas dalam memberikan pelayanan sehingga berakibat sangat fatal. Terlebih lagi diputuskannya kerja sama pelayanan jaminan kesehatan Bali Mandara (JKBM) Rumah Sakit Swasta di Buleleng oleh Pemkab Buleleng berdampak pada pasien JKBM beralih ke RSUD Buleleng. Seiring gencarnya pemerintah pusat dan provinsi memberikan jaminan kesehatan berupa JKBM mestinya harus didukung dengan pelayanan yang baik tanpa membedakan status sosial pasien. Seorang pasien JKBM di RSUD Buleleng sudah 6 hari di 
rawat di RSUD Buleleng karena sakit demam berdarah (DBD), saat pertama masuk ke RSUD Buleleng ia kesulitan mendapatkan kamar dengan alasan kamar rumah sakit sudah penuh ia harus menunggu lama di UGD yaitu dari malam hari pukul 01.00 sampai pukul 16.00 baru mendapatkan kamar (http://bali.tribunnews.com/2016/02/04/).

Kinerja merupakan gambaran dari pencapaian pelaksanaan suatu kegiatan/program/kebiajakan untuk mewujudkan sasaran, tujuan, misi dan visi organisasi. Menurut Mardiasmo (2002), sistem pengukuran kinerja sektor publik adalah suatu sistem yang bertujuan untuk membantu manajer sektor publik menilai pencapaian suatu strategi melalui alat ukur finansial dan nonfinansial. Sistem pengukuran kinerja ini dapat dijadikan sebagai alat pengendalian organisasi.

Maksud dilakukannya pengukuran kinerja organisasi publik antara lain :

1. Membantu memperbaiki kinerja pemerintah agar dapat berfokus pada tujuan dan sasaran program unit kerja yang pada akhirnya akan meningkatkan efisiensi dan efektivitas organisasi sektor publik dalam memberikan layanan kepada masyarakat.

2. Ukuran kinerja sektor publik digunakan untuk pengalokasian sumber daya dan pembuatan keputusan.

3. Untuk mewujudkan tanggung jawab publik dan memperbaiki komunikasi kelembagaan.

Dengan pernyataan kondisi-kondisi yang seperti itu, maka penulis berkeinginan untuk meneliti apakah pelayanan JKBM di RSUD Buleleng dapat membantu dalam pencapaian kepuasan pelayanan publik yang berkualitas melalui mini riset yang berjudul "Kinerja RSUD Kabupaten Buleleng Dalam Pelayanan Terhadap Pasien JKBM".

Berdasarkan uraian latar belakang masalah di atas, masalah yang akan dicari penyelesaiannya melalui penelitian ini yaitu bagaimana sejarah dan Profil RSUD Buleleng, bagaimana sistem pemberlakuan JKBM di RSUD Buleleng, apakah tujuan dibentuknya JKBM sudah sesuai dengan realita yang ada di masyarakat, bagaimana respon dan tanggapan masyarakat dengan adanya JKBM, Apakah kualitas pelayanan RSUD Buleleng terhadap pasien JKBM sudah baik, serta mengapa RS Swasta di Buleleng menghentikan program JKBM.

\section{Hasil dan Pembahasan}

\subsection{Sejarah dan Profil Rumah Sakit Umum Daerah Buleleng}

Rumah Sakit Umum Daerah Kabupaten Buleleng berdiri pada tahun 1955 di jalan Veteran No.1 Singaraja (Kini Kantor Dinas Kesehatan Kabupaten Buleleng) pada saat itu digunakan sebagai RS Tentara dan juga untuk umum. Pada tahun 1959 RSUD Kabupaten Buleleng pindah ke jalan Ngurah Rai No.30 sekaligus menandai alih fungsi menjadi RSUD kelas C milik Depkes RI. Berdasarkan keputusan Bupati Buleleng No. 511 tertanggal 22 September 1996 RSUD difungsikan sebagai uji coba menuju unit swadana. Pada tanggal 20 Mei 1997, berdasarkan SK MenKes RI No 476/1997, RSUD Kabupaten Buleleng ditetapkan sebagai RS type B Non Pendidikan. Kemudian berdasarkan SK Bupati No 524 tanggal 8 Oktober 2003 menetapkan RSUD Kabupaten Buleleng sebagai unit Swadana dan ditindak lanjuti dengan SK Bupati Buleleng No 61 tanggal 24 Maret 2004 tentang penetapan tariff kelas II, I, Utama dan Madya Utama Berdasarkan Peraturan Bupati No. 589 tanggal 26 Desember 2006 ditetapkan Status Pengelolaan Keuangan Rumah Sakit Umum Daerah Kabupaten Buleleng Sebagai Pola Pengelolaan Keuangan Badan Layanan Umum Bertahap. Berdasarkan Keputusan Buleleng No 445/405/hk/2009 tanggal 1 Juli 2009 ditetapkan Status Pengelolaan Keuangan Rumah Sakit Umum Daerah Kabupaten Buleleng Sebagai Badan Layanan Umum Daerah (BLUD).

Rumah Sakit Umum Daerah (RSUD) Kabupaten Buleleng adalah Rumah Sakit Pemerintah type B Non Pendidikan yang berdiri pada lokasi strategis di jalan Ngurah Rai 31 Singaraja, ditengah kota dengan mudah dijangkau dengan kendaraan umum serta berdekatan dengan kawasan industry dan perumahan yang potensial. Rumah Sakit Umum Daerah Kabupaten Buleleng berdiri sejak tahun 1955 dan berdasarkan Keputusan Bupati Buleleng No 445/405/hk/2009 tanggal 1 Juli 2009 ditetapkan Status Pengelolaan Keuangan Rumah Sakit Umum Daerah Kabupaten Buleleng Sebagai Badan Layanan Umum Daerah (BLUD). Dengan Bentuk BLUD, RSUD Kabupaten Buleleng merupakan rumah sakit non 
profit yang tidak mencari keuntungan dari pelayanan yang diberikan. RSUD Kabupaten Buleleng berkapasitas 242tempat tidur dengan 13 ruang rawat inap. Ketersediaan tempat rawat inap yang memadai agar pelayanan bisa dilaksanakan secara optimal. Rumah Sakit Umum Daerah Kabupaten Buleleng telah bekerjasama dengan beberapa BUMN dan Bank milik pemerintah seperti PDAM, BNI, dan BPD. Kerjasama ini merupakan peluang menarik, karena secara signifikan Rumah Sakit Umum Daerah Kabupaten Buleleng memiliki captive market yang bervariatif. Kondisi keuangan setiap tahunnya telah memperlihatkan sinyal yang menggembirakan karena mampu meningkatkan cost recovery, meskipun belum menunjukkan profit yang diharapkan. Berdasarkan analisa pembiyaan diharapkan biaya operasional akan semakin efisien sehingga mampu memperlihatkan profit yang diharapkan. Upaya pengembangan manajemen dititikberatkan kepada pembelajaran dan pengembangan SDM, memperkuat proses bisnis internal, pendekatan pelanggan dan efektifitas pengelolaan keuangan. Pendekatan ini dimaksudkan agar dengan SDM yang berkompetensi tinggi mampu meningkatkan kinerja keuangan secara bermakna.

Rumah Sakit Umum Daerah Kabupaten Buleleng memiliki Isue-Isue Strategis (Strategic Issues) yang memiliki :

a. Dokter spesialis dari berbagai jenis keahlian tenaga pendukung dan peralatan kedokteran masih belum memadai, merupakan suatu hambatan yang dapat mempersulit pelayanan yang diberikan oleh para dokter spesialis di RSUD Kabupaten Buleleng.

b. Bangunan RS baru dan berlokasi strategis merupakan peluang besar, namun system manajerial dan pendanaan untuk pemeliharaan sarana prasarana RS yang belum memadai, bisa menyebabkan terjadinya berbagai keluhan yang tidak menguntungkan rumah sakit dan dapat memperlambat pembentukan branding rumah sakit.

c. Mindsetmasyarakat pengguna semakin matang dan dewasa dalam hal pelayanan kesehatan, pada sisi lain mindset karyawan dengan orientasi terhadap pelanggan belum maksimal, sehingga ada kemungkinan bisa terjadinya ketidak-puasan pelanggan berkaitan dengan service yang diberikan berdasarkan mindset karyawan.

d. Kontrak dengan berbagai perusahaan swasta, BUMN dan customer maintain belum terpupuk dengan baik dan pemasaran yang belum optimal, sehingga RS berisiko kehilangan captive market.

e. Program JKBM yang dilaksankan awal tahun 2010, diharapkan akan mampu meningkatkan kapasitas masyarakat dalam memperoleh pelayanan kesehatan rumah sakit, pada sisi lain dibutuhkan kesiapan manajemen rumah sakit untuk penyediaan ruang rawat inap kelas III sehingga demand masyarakat yang meningkat dpat terakomodasi oleh rumah sakit.

Produk Jasa yang Ditawarkan :

1. Pelayanan Penyakit Dalam (Internist)

2. Pelayanan Bedah, terdiri dari :
a. Bedah Tulang

b. Bedah Umum

3. Pelayanan Kesehatan Anak (Pediatric)

4. Pelayanan Obstetri dan Ginekologi (Obstetry gynaecology)

5. Pelayanan Penyakit Syaraf (Neurology)

6. Pelayanan Mata (Opthalmology)

7. Pelayanan THT (Throat, Nose \& ear)

8. Pelayanan Kulit Kelamin

9. Pelayanan Jantung dan Pembuluh Darah (Cardiology)

10. Pelayanan Paru (Lungs)

11. Pelayanan Jiwa (Psychlatry)

12. Pelayanan Gigi dan Mulut (Dental)

13. Pelayanan Fisioterapi (physiotherapy)

14. Hemodialisa (Haemodialysis)

15. ICU (Intensive Care Unit)

16. ICCU (Intensive Coronary Care Unit)

17. Intermediate 
18. Perinatologi (Perinatology)

19. Kamar Operasi (Central Operating Theater)

20. Pelayanan HIV/AIDS

Rumah Sakit Umum Daerah Buleleng mempunyai alasan dalam memberikan produk pelayanan yaitu :

1. Menjawab tuntutan masyarakat akan pelayanan kesehatan individu yang sesuai standar pelayanan berdasarkan hasil kajian melalui studi kelayakan diwilayah kabupaten Buleleng dan sekitarnya yang memerlukan institusi pelayanan masyarakat dibidang rumah sakit.

2. Segmen pasar di semua lapisan, yang membutuhkan layanan yang berkualitas standar nasional dan memenuhi persyaratan-persyaratan tertentu yang sesuai dengan ketentuan system asuransi kesehatan.

3. Memberikan pelayanan kesehatan individu kepada masyarakat yang juga dapat menguntungkan semua stakeholder.

Rumah Sakit Umum Daerah Buleleng dalam melayani pasiennya mempunyai keunikan pelayanan tersendiri yaitu :

a. Memberikan pelayanan dengan sentuhan budaya lokal.

b. Memberikan pelayanan kesehatan individu dengan dukungan pelayanan customer service 24 jam.

c. Menyediakan pelayanan rawat inap dengan tingkat privacy dan kenyamanan yang tinggi utamanya pada ruang VIP.

d. Menyediakan pelayanan CT scan

\subsection{Sistem Pemberlakuan JKBM}

Dinas kesehatan Bali memutuskan untuk memberlakukan Kartu Jaminan Kesehatan Bali Mandara (JKBM) atau kartu pelayanan kesehatan gratis bagi masyarakat miskin mulai Desember mendatang. Keputusan pemberlakuan Kartu JKBM ini bertujuan untuk mempermudah proses adminitrasi bagi pasien miskin ketika berobat ke Puskesmas atau rumah sakit.

Selama pelayanan ini pelayanan JKBM diberikan kepada masyarakat miskin dengan menunjukan kartu tanda penduduk, surat keterangan miskin dari kepala desa dan surat pengantar puskesmas apabila pasien berobat ke rumah sakit. Kepala Dinas Kesehatan Bali Dr.Nyoman Sutedja pada keterangannya di Renon, menyatakan pemberlakuan Kartu JKBM akan diberlakukan secara bertahap. Pada tahap pertama akan dicetak 30.000 kartu sesuai kesiapan kabupaten/kota. Melihat kesiapan SDM dan peralatan, ada 5 kabupaten yang sudah siap cetak seperti Buleleng, Denpasar, Badung, Gianyar, dan Klungkung ujar Nyoman Sutedja.

Nyoman Sutedja menyebutkan menurut rencana Dinas Kesehatan Bali akan menyiapkan sekitar 500.000 kartu JKBM bagi kepala keluarga miskin di Bali. Dimana satu keluarga JKBM yang dapat digunakan oleh seluruh amggota keluarga akan mendapatkan satu kartu JKBM yang dapat digunakan oleh seluruh anggota keluarga dengn hanya menyebutkan, nomor registrasi kartu karena sistem JKBM akan dioprasionalkan secara online. Hal ini akan memudahkan pelayanan JKBM yang sesuai dengan standar nasional jika pelayanan kesehatan yang bersangkutan diterima langsung oleh masyarakat yang membutuhkannya. Selain kendala aturan, JKBM juga terkendala intergrasi data sebagaimana yang disiapkan oleh Sistem Informasi Kesehatan (SIK) secara nasional. "SIK yang dilakukan JKBM itu berbeda dengan SIK nasional. Sekalipun JKBM masih terkendala dengan kebijakan nasional, tetapi pelayanan kepada masyarakat agar tetap dilakukan sekalipun secara manual. Melalui JKBM diharapkan meningkatnya kualitas pelayanan kesehatan.

Peningkatan pasien JKBM tentunya bukan karena penurunan derajat kesehatan masyarakat tetapi justru karena program ini telah dikenal dan dipahami oleh seluruh lapisan masyarakat Bali.

Persyaratan indentitas peserta JKBM :

a. Fotocopy KTP Bali bagi masyarakat yang berumur di atas 17 (tujuh blas ) tahun.

b. Fotocopy KK bagi yang berumur di bawah 17 (tujuh belas) tahun. 
c. Bayi (berumur kurang dari 1 tahun ) menyerahkan fotocopy identitas orang tua dan surat keterangan kelahiran.

d. Masyarakat yang mengalami kelainan jiwa dapat menggunakan fotocopy surat keterangan mengalami kelainan jiwa dari kelian Banjar atau Kepada Desa atau

e. Menggunakan kartu elektronik JKBM.

\subsection{Tujuan dibentuknya JKBM dengan Realita yang Ada di Masyarakat.}

"Tujuan di bentuk dan diberlakukannya JKBM di sini (RSUD Buleleng) sudah sesuai dengan realita yang ada dimasyarakat karena kami sudah berusaha semaksimal mungkin untuk meningkatkan mutu/kualitas pelayanan kami, tetapi mungkin ada beberapa pasien yang merasa tidak puas dengan pelayanan kami, karena pendapat orang berbeda-beda tergantung mereka menilainya dan kami akan selalu mengusahakan pelayanan yang terbaik demi menunjang terlaksananya kebijakan pemerintah dalam mensejahterakan masyarakat Buleleng".

Jaminan kesehatan Bali mandara (JKBM) Program ini bertujuan meningkatkan akses \& mutu pelayanan kesehatan Provinsi Bali. Melalui JKBM diharapkan meningkatkan cakupan masyarakat Bali yang mendapatkan pelayanan kesehatan serta meningkatkan kualitas pelayanan kesehatan. JKBM diperuntukan bagi seluruh masyarakat bali yang belum memiliki jaminan kesehatan. Pelayanan dilaksanakan diseluruh masyarakat bali yang belum meiliki jaminan kesehatan. Pelayanan dilaksanakan di seluruh Puskesmas Pembantu, Puskesmas, dan Rumah Sakit.

Pemerintahan Dalam dua tahun pelaksanaannya, program JKBM telah mampu melayani lebih dari 6 juta pasien, dengan perincian pada tahun 2010 tercatat sebanyak 2.535.886 jiwa dan pada tahun 2011 meningkat menjadi 2.936.886 jiwa. Sementara hingga pertengahan tahun 2012, JKBM telah melayani lebih dari satu juta masyarakat. Hal ini menandakan kalau program kesehatan ini merupakan salah satu kebijakan populer dan pelaksanaannya makin eksis dan sangat bermanfaat bagi masyarakat Bali. Selain itu, JKBM juga berdampak positif pada penurunan Angka Kematian Bayi di Provinsi Bali. Angka kematian bayi di Provinsi Bali pada akhir 2011 sebesar 6,52 per 1.000 angka kelahiran hidup atau mengalami penurunan yang sangat berarti dari tahun sebelumnya yang tercatat 7,10 . la menambahkan, selain kematian balita yang menurun drastis, juga disertai dengan keberhasilan menekan Angka Kematian Ibu (AKI) melahirkan dan meningkatkan Sosialisasi budaya hidup bersih juga terus dilakukan dengan menggandeng sejumlah elemen masyarakat diantaranya PKK. Keterpaduan program JKBM dan upaya preventif diharapkan mampu mewujudkan masyarakat Bali yang sehat sebagai syarat mutlak suksesnya program Bali Mandara.

Tujuan diberlakukannya JKBM di RSUD Buleleng tidak sedikit yang menyatakan bahwa pelayanan JKBM belum sesuai dengan realita yang ada dimana masyarakat banyak mengeluh mengenai JKBM, karena keterlambatan pelayanan dan kebanyakan pasien yang mengunakan JKBM tersebut merasa tidak nyaman. Sehingga masyarakat yang ekonominya tinggi langsung mengunakan jalur umum dengan terpaksa tapi masyarakat miskin tidak bisa mengunakan jalur umum malah mereka menunggu pelayanan JKBM. Walaupun banyak masyarakat yang merasa tidak nyaman kerumah sakit menggunakan pelayanan JKBM karena adanya faktor ekonomi, karena kebanyakan masyarakat buleleng memiliki tingkat prekonomian yang sangat rendah sehingga tidak bisa menggunakan prinsip lain lagi. JKBM mempunyai tujuan umum dan khusus agar masyarakat Bali tercapai derajat kesehatan masyarakat yang optimal secara efektif dan efesien. Tujuan khususnya yaitu meningkatkan cakupan masyarakat bali yang mendapat pelayanan kesehatan di puskemas serta jaringan dan di rumah sakit meningkatnya kualitas pelayanan kesehatan bagi seluruh masyarakat bali, terselenggaranya pengelolaan keuangan yang transparan dan akuntabel,

JKBM pelaksanan program JKBM berdasarkan pada undang-undang dasar tahun 2007 tentang pembagian urusan pemerintahan provinsi dan kabupaten atau kota pada sub bidang pembiayaan kesehatan tugas pemerintahan daerah ditingkat provinsi. Tata laksanaan kepersertaan adapun ketentuan umum tata laksana kepersertaan JKBM yaitu peserta JKBM adalah setiap penduduk yang sudah terdaftar dan memiliki KTP Bali dan 
anggota keluarganya memiliki jaminan kesehatan atau dengan identitas kartu peserta JKBM yang terdaftar berdasarkan pendataan di masing-masing banjar pada kabupaten atau kota Bupati atau Walikota menetapkan jumlah peserta JKBM penetapan peserta JKBM perlu dilakukan updating data secara berkala terkait dengan terjadinya mutasi peserta yang meninggal, pemberlakuan mutasi tersebut menjadi sah setelah pemberlakuan mutasi tersebut menjadi sah setelah adanya addendum surat keputusan bupati atau walikota.dan puskemas setempat dinas kesehatan provinsi atau pengelola JKBM provinsi pada masa transisi selama 3 bulan pemerintahan daerah kabupaten atau kota yang telah menetapkan jumlah nama peserta JKBM namun belum memiliki KTP Bali. Dengan menggunakan surat keterangan sebagai penduduk Bali dan tidak memiliki jaminan kesehatan dari kepala desa selama proses penerbitan dan distribusi kartu JKBM belum selesai pencetakan dan penggandaan blanko kartu peserta menjadi tanggung jawab pemerintahan kabupaten atau kota setempat jika peserta JKBM langsung menjadi peserta baru dengan pembuatan kartu diusulkan setelah dilaporkan melalui mekanisme pendapatan diatas sebaliknya bagi peserta yang meninggal dunia langsung hilang haknya sebagai kepemilkan kartu peserta JKBM bila terjadi kehilangan kartu JKBM peserta tetap dapat memperoleh pelayanan kesehatan, dilakukan dengan meunjukan ktp.

\subsection{Respon dan tanggapan masyarakat dengan adanya JKBM}

"Respon masyarakat dengan adanya JKBM ini sangat bagus begitu juga dengan tanggapannya karena dilihat dari jumlah pasien JKBM setiap tahun selalu meningkat dengan ini dapat kami simpulkan bahwa respon dan tanggapan masyarakat sangat bagus terhadap pelayanan JKBM di RSUD Buleleng ini "

Dengan diadakannya atau diterbitkannya kebijakan pemerintah tentang mensejahterakan masyarakat miskin dalam pelayanan kesehatan maka pemerintah provinsi Bali meluncurkan kartu JKBM (Jaminan Kesehatan Bali Mandara) dengan diterbitkannya kartu ini pemerintah megharapkan agar masyarakat menengah kebawah mendapatkan pelayanan kesehatan gratis.

Pertama kali diterbitkannya kartu JKBM, masyarakatpun merespon dengan sangat senang karena dapat mengurangi beban masyarakat saat membutuhkan pelayanan kesehatan, tetapi seiring berjalannya waktu pelayanan JKBM di RSUD Buleleng menurut masyarakat menurun, dari kurangnya kamar yang tersedia bagi pasien kelas III atau golongan kebawah, kurang ramahnya pelayanan yang diberikan, menurut informasi dari salah satu pasien yang menggunakan jalur JKBM, waktu ingin berobat ke RSUD Buleleng karena mengalami kecelakaan saat bekerja akibatnya jari tangannya hampir saja putus, lalu saat ingin berobat dia ditanyai oleh salah satu karyawan rumah sakit ingin menggunakan jalur umum atau jalur apa, lalu karena pasien ini merupakan masyarakat yang kurang mampu maka dia menggunakan jalur JKBM, tetapi respon yang ditunjukkan rumah sakit pun sangat lama sehingga membuat pasien tidak mampu untuk menahan sakit maka dia segera merubah jalur JKBM ke jalur umum lalu tidak lama kemudian dia langsung mendapatkan pelayanan. Dari kasus tersebut jelas sekali bahwa pelayanan di RSUD Buleleng dinilai masih kurang sigap terhadap pasien pengguna jalur JKBM, ini merupakan deskriminasi terhadap pasien pengguna JKBM dan pengguna jalur umum. Tidak sedikit masyarakat yang beranggapan bahwa pelayanan kesehatan jalur JKBM masih kurang memuaskan pasien, tetapi walaupun begitu banyak masyarakat yang senang dan bersyukur dengan adanya kartu JKBM ini karena tidak ada pilihan lain selain menggunakan jalur JKBM ini.

\subsection{Kualitas Pelayanan Terhadap Pasien JKBM}

"Kami sudah berusaha dengan keras agar kualitas yang kami berikan kepada pasien JKBM di RSUD Buleleng terlaksana dengan baik dan memiliki kualitas yang bagus, dan kami mengharapkan pasien kami senang dengan kualitas pelayanan yang kami berikan, walaupun begitu pasti ada kekurangan pelayanan yang kami berikan tergantung bagaimana pasien itu menanggapinya, peralatan yang ada di RSUD Buleleng bisa dibilang sudah cukup untuk mampu meningkatkan kualitas pelayanan kami" 
RSUD Buleleng selalu berkomitmen untuk mengupayakan pelayanan kesehatan yang berkualitas, aktivitas pelayanan kesehatan yang telah dilakukan setiap tahunnya dievaluasi dan dilaporkan dalam bentuk laporan tahunan dengan mengedepankan pancapaian kinerja dan pelayanan di semua instalasi rumah yang dibandingkan dengan standar pelayanan minimal yang harus dicapai. Keberhasilan program pembangunan kesehatan ditentukan tersedia atau tidaknya biaya kesehatan. Pada saat ini pengaruh berbagai faktor (inflasi, perubahan pola penyakit, perubahan pola pelayanan kesehatan, perubahan pola hubungan dokter-pasien, kemajuan iptek kedokteran dan perkembangan spesialisasi) membuat biaya kesehatan cenderung meningkat. Akses masyarakat terhadap pelayanan kesehatan terutama bagi penduduk tidak mampu sangat rendah, dan terlebih lagi apabila pembiayaan ditanggung sendiri. Tujuan program ini untuk meningkatkan akses dan mutu pelayanan kesehatan masayarakat Bali, sehingga masyarakat yang sakit bisa cepat diatasi dan ditanggung oleh pemerintah. Meningkatkan kualitas pelayanan kesehatan bagi masyarakat. Jaminan ini memberikan kepastian kepada masyarakat bahwa mereka sudah mempunyai jaminan akan kesehatan itu sendiri.

\subsection{Alasan RS Swasta di Buleleng menghentikan program JKBM disusul RSUD Buleleng}

Pemerintah Kabupaten Buleleng pada 2015 menghentikan jejaring pelayanan Jaminan Kesehatan Bali Mandara itu karena kesulitan menanggung biaya pendampingannya. " Klaim RS Swasta disana terlalu tinggi sehingga biaya yang dikeluarkan Pemkab Buleleng untuk JKBM menjadi lebih besar dari perencanaan, "kata Kepala Dinas Kesehatan Provinsi Bali Dr. Ketut Suarjaya, di Denpasar, kamis (18/12/2014). la mengemukakan, sebelumnya Pemkab Buleleng dalam mendukung program unggulan Pemrov Bali di bidang kesehatan itu mengajak tiga RS swasta yakni RS Kerta Usada, Karya Dharma Usada, Parama Sidhi sebagai jejaring JKBM dan sekarang yang disusul dengan RSUD tahun 2016. Peserta JKBM dapat memilih pergi ke salah satu RS swasta itu dalam memanfaatkan layanan kesehatan gratis, selain ke Rumah Sakit Umum Daerah Buleleng. Namun dalam perjalanannya, ucap dia, klaim dari tiga RS swasta tersebut per bulan total berkisar Rp3,5 miliar. Sedangkan klaim dari RSUD Buleleng sebesar Rp2,5 miliar, belum lagi klaim dari puskesmas. "sehingga Pemkab Buleleng agak kesulitan menanggung biaya pendampingannya,"ucapnya. Pemkab Buleleng, kata Suarjaya, untuk tahun ini mengalokasikan dana pendampingan JKBM sebesar Rp 22 miliar sedangkan dari Pemrov Bali untuk daerah ini Rp 24 miliar. "kami tidak kuat karena utang yang tahun lalu masih, sekarang ditambah menalangi utang tahun ini. Oleh karena itu, untuk 2015 akan memutus kontrak dengan Kerta Usada, Karya Dharma Usada dan Parama sidhi, sehingga praktis nantinya JKBM hanya akan dilayani oleh RSUD saja,"ujar suarjaya. Untuk mengantisipasi membeludaknya pasien JKBM ke RSUD Buleleng, Suarjaya mengharapkan masyarakat dapat terlebih dahulu memanfaatkan pelayanan di puskesmas. "puskesmas memang akan dioptimalisasi sehingga tidak sedikit-sedikit masyarakat harus ke RSUD, terutama untuk kasus-kasus yang ringan. Di puskesmas itu harus bisa mengobati 155 penyakit,"ucapnya. Selain itu juga sudah ada Peraturan Gubernur Bali Nomor 7 tahun 2014 yang intinya mengatur mekanisme rujukan. Dengan demikian, masyarakat harus memanfaatkan puskesmas dulu sebagai pelayanan dasar. Dan terkait dengan JKBM, pihak dinas kesehatan Kabupaten Buleleng lebih jauh membahas terkait angka hutang dalam Anggaran Pendapatan dan Belanja Daerah yang sempat mencapai angka Rp16 miliar kepada Provinsi Bali. Dimana, angka yang membebani APBD Kabupaten Buleleng untuk pelayanan kesehatan tersebut telah diselesaikan hingga menyisakan hutang Rp8 miliar yang harus dibayarkan kepada pihak Provinsi Bali dalam layanan JKBM. Hal tersebut disampaikan KASI JPKM Dinas Kesehatan Kabupaten Buleleng, Gede Suratnaya, yang menyebut salah satu factor penyebabnya adalah tidak digunakannya Puskesmas sebagai sarana pelayanan pertama. Dimana, lanjutnya, fakta bahwa rumah sakit umum selalu menjadi puskesmas raksasa untuk setiap pelayanan kesehatan yang seharusnya bisa diselesaikan di tingkat puskemas. Menurutnya, perlu ada pembatasan untuk pemberian fasilitas kesehatan yang harus ditanggung oleh anggaran pemerintah daerah. Sehingga, program JKN dianggap mampu menjadi filter yang mampu menyaring kebutuhan 
masyarakat khususnya di tingkat ekonomi tidak mapu agar betul-betul merasakan pelayanan kesehatan dari pemerintah. Hutang tersebut terkait pembayaran yang bersifat sharring dengan pihak Provinsi Bali. Sehingga, hutang yang muncul tersebut disebabkan pemberlakuan sharring pembayaran dan bukan kepada pihak provider atau rumah sakit yang menjadi berkewajiban memberi pelayanan.

Kepala Dinas Kesehatan Buleleng Dr.IGN Maha Pramana, juga menjelaskan pemerintah menghentikan kerjasama pelayanan JKBM dengan rumah sakit swasta karena dorongan regulasi dimana rumah sakit swasta dituntut lebih fokus melayani pasien menggunakan JKN. Sementara rumah sakit daerah dan puskesmas, tetap melayani jaminan sosial daerah sembari melakukan integrasi dengan system jaminan sosial. "bukan berarti swasta tidak melayani JKBM,tidak. Sekarang sambil menunggu integrasi system dan penyesuaian, setahun ini hanya RSUD dan Puskesmas saja yang melayani JKBM,"ujar Mahapramana. Menurutnya integrasi sistem itu merupakan amanah Undang-undang Nomor 40 tahun 2004 tentang system Jaminan Sosial Nasional. la memastikan pemutusan kerjasama dengan rumah sakit swasta bukan karena alasan teknis lainnya. Meski rumah sakit swasta tak lagi melayani JKBM, Mahapramana menegaskan RSUD Buleleng dan puskesmas yang ada di Buleleng, tak akan menolak pasien JKBM. Apalagi kini RSUD Buleleng telah menambah seratus tempat tidur untuk kelas tiga. Pemerintah juga telah menyediakan 60 tempat tidur. Kalaupun nantinya kapasitas tempat tidur di kelas tiga pelayanan standar JKBM di RSUD Buleleng Penuh, RSUD harus tetap menerima pasien dan bisa menempatkannya di ruangan lain. Tetapi pada kenyataannya tidak demikian. RSUD Buleleng memberhentikan Program JKBM pada tahun 2016 dengan alasan pasien yang menggunakan JKBM semua beralih ke RSUD dan RSUD sudah tidak bisa menampung dan Program JKBM sudah beralih ke Provinsi. Buleleng Dapat Jatah KIS sebanyak 257.709. Dengan di berhentikannya Program JKBM, Kabupaten Buleleng akan mendapatkan kartu Indonesia Sehat (KIS) bagi warga miskin sebanyak 257.709 kartu sehat. Sementara jumlah keluarga miskin di buleleng mencapai 42.929. kuota KIS ini berdasarkan SK Menteri Sosial Nomor 170 tahun 2015. "Sk ini baru terbit bulan Desember kemarin, dan data basenya dari kementerian Sosial sudah kami terima. Jadi yang menentukan siapa penerimanya,bukan kami. Tapi sudah ada dari kementerian,"kata Made Sukmayanti, Kepala Badan Pengelola jaminan Sosial (BPJS) cabang singaraja. Kartu Indonesia sehat akan disebar pada bulan ini juga dan pembagian harus tepat sasaran dan harus tuntas pada 29 Februari mendatang. Sukmawati menyatakan akan ada verifikasi dari pemerintah jika ada warga miskin yang tidak mendaptkan KIS. Sementara Kepala Dinas Sosial Buleleng Gede Komang, mengatakan jalur distribusi KIS akan menjadi kewenangan BPJS Kesehatan bersama pihak ekspedisi. Pihaknya hanya melakukan validasi serta verifikasi data keluarga miskin, agar kartu yang disalurkan tepat sasaran. Kartu yang dibagikan pada tahun 2016 ini, merupakan hasil verifikasi dan validasi data di tahun 2014 lalu. Sementara hasil validasi data di tahun 2015, akan digunakan sebagai basis data penerima KIS pada tahun 2017 mendatang. Gede komang berharap jika ada warga miskin yang tidak mendapatkan KIS supaya segera melaporkan ke Dinas Sosial Kabupaten Buleleng supaya segera bisa dilakukan verifikasi data.

\section{Simpulan dan Saran}

Rumah Sakit Umum Daerah Kabupaten Buleleng berdiri pada tahun 1955 di jalan Veteran No.1 Singaraja (Kini Kantor Dinas Kesehatan Kabupaten Buleleng) pada saat itu digunakan sebagai RS Tentara dan juga untuk umum. Pada tahun 1959 RSUD Kabupaten Buleleng pindah ke jalan Ngurah Rai No.30 sekaligus menandai alih fungsi menjadi RSUD kelas C milik Depkes RI. Berdasarkan keputusan Bupati Buleleng No. 511 tertanggal 22 September 1996 RSUD difungsikan sebagai uji coba menuju unit swadana. Pada tanggal 20 Mei 1997, berdasarkan SK MenKes RI No 476/1997, RSUD Kabupaten Buleleng ditetapkan sebagai RS type B Non Pendidikan. Kemudian berdasarkan SK Bupati No 524 tanggal 8 Oktober 2003 menetapkan RSUD Kabupaten Buleleng sebagai unit Swadana dan ditindak lanjuti dengan SK Bupati Buleleng No 61 tanggal 24 Maret 2004 tentang penetapan tariff kelas II, I, Utama dan Madya Utama Berdasarkan Peraturan Bupati No. 589 tanggal 26 
Desember 2006 ditetapkan Status Pengelolaan Keuangan Rumah Sakit Umum Daerah Kabupaten Buleleng Sebagai Pola Pengelolaan Keuangan Badan Layanan Umum Bertahap.

Rumah Sakit Umum Daerah Kabupaten Buleleng memiliki Isue-Isue Strategis (Strategic Issues) yang memiliki :

a. Dokter spesialis dari berbagai jenis keahlian tenaga pendukung dan peralatan kedokteran masih belum memadai, merupakan suatu hambatan yang dapat mempersulit pelayanan yang diberikan oleh para dokter spesialis di RSUD Kabupaten Buleleng.

b. Bangunan RS baru dan berlokasi strategis merupakan peluang besar, namun system manajerial dan pendanaan untuk pemeliharaan sarana prasarana RS yang belum memadai, bisa menyebabkan terjadinya berbagai keluhan yang tidak menguntungkan rumah sakit dan dapat memperlambat pembentukan branding rumah sakit.

c. Mindsetmasyarakat pengguna semakin matang dan dewasa dalam hal pelayanan kesehatan, pada sisi lain mindset karyawan dengan orientasi terhadap pelanggan belum maksimal, sehingga ada kemungkinan bisa terjadinya ketidak-puasan pelanggan berkaitan dengan service yang diberikan berdasarkan mindset karyawan.

d. Kontrak dengan berbagai perusahaan swasta, BUMN dan customer maintain belum terpupuk dengan baik dan pemasaran yang belum optimal, sehingga RS berisiko kehilangan captive market.

Program JKBM yang dilaksankan awal tahun 2010, diharapkan akan mampu meningkatkan kapasitas masyarakat dalam memperoleh pelayanan kesehatan rumah sakit, pada sisi lain dibutuhkan kesiapan manajemen rumah sakit untuk penyediaan ruang rawat inap kelas III sehingga demand masyarakat yang meningkat dapat terakomodasi oleh rumah sakit. Adapun Persyaratan indentitas peserta JKBM antara lain:

a. Fotocopy KTP Bali bagi masyarakat yang berumur di atas 17 (tujuh blas ) tahun.

b. Fotocopy KK bagi yang berumur di bawah 17 (tujuh belas) tahun.

c. Bayi (berumur kurang dari 1 tahun ) menyerahkan fotocopy identitas orang tua dan surat keterangan kelahiran.

d. Masyarakat yang mengalami kelainan jiwa dapat menggunakan fotocopy surat keterangan mengalami kelainan jiwa dari kelian Banjar atau Kepada Desa atau

e. Menggunakan kartu elektronik JKBM.

Jaminan kesehatan Bali mandara (JKBM) Program ini bertujuan meningkatkan akses \& mutu pelayanan kesehatan Provinsi Bali. Melalui JKBM diharapkan meningkatkan cakupan masyarakat Bali yang mendapatkan pelayanan kesehatan serta meningkatkan kualitas pelayanan kesehatan. JKBM diperuntukan bagi seluruh masyarakat bali yang belum memiliki jaminan kesehatan. Pelayanan dilaksanakan diseluruh masyarakat bali yang belum meiliki jaminan kesehatan. Pelayanan dilaksanakan di seluruh Puskesmas Pembantu, Puskesmas, dan Rumah Sakit. Respon masyarakat dengan adanya JKBM ini sangat bagus begitu juga dengan tanggapannya karena dilihat dari jumlah pasien JKBM setiap tahun selalu meningkat dengan ini dapat kami simpulkan bahwa respon dan tanggapan masyarakat sangat bagus terhadap pelayanan JKBM di RSUD Buleleng ini.

RSUD Buleleng selalu berkomitmen untuk mengupayakan pelayanan kesehatan yang berkualitas, aktivitas pelayanan kesehatan yang telah dilakukan setiap tahunnya dievaluasi dan dilaporkan dalam bentuk laporan tahunan dengan mengedepankan pancapaian kinerja dan pelayanan di semua instalasi rumah yang dibandingkan dengan standar pelayanan minimal yang harus dicapai. Keberhasilan program pembangunan kesehatan ditentukan tersedia atau tidaknya biaya kesehatan. Pada saat ini pengaruh berbagai faktor (inflasi, perubahan pola penyakit, perubahan pola pelayanan kesehatan, perubahan pola hubungan dokter-pasien, kemajuan iptek kedokteran dan perkembangan spesialisasi) membuat biaya kesehatan cenderung meningkat. Akses masyarakat terhadap pelayanan kesehatan terutama bagi penduduk tidak mampu sangat rendah, dan terlebih lagi apabila pembiayaan ditanggung sendiri. Tujuan program ini untuk meningkatkan akses dan mutu pelayanan kesehatan masayarakat Bali, sehingga masyarakat yang sakit bisa cepat diatasi dan ditanggung oleh pemerintah. Meningkatkan kualitas pelayanan kesehatan bagi masyarakat. Jaminan ini memberikan kepastian kepada masyarakat bahwa mereka sudah mempunyai jaminan akan kesehatan itu sendiri. 
Tetapi pada tahun 2015 Program Pelayanan JKBM di hentikan. Pemerintah Kabupaten Buleleng pada 2015 menghentikan jejaring pelayanan Jaminan Kesehatan Bali Mandara itu karena kesulitan menanggung biaya pendampingannya. "Klaim RS Swasta disana terlalu tinggi sehingga biaya yang dikeluarkan Pemkab Buleleng untuk JKBM menjadi lebih besar dari perencanaan, " kata Kepala Dinas Kesehatan Provinsi Bali Dr. Ketut Suarjaya, di Denpasar, kamis (18/12/2014). la mengemukakan, sebelumnya Pemkab Buleleng dalam mendukung program unggulan Pemrov Bali di bidang kesehatan itu mengajak tiga RS swasta yakni RS Kerta Usada, Karya Dharma Usada, Parama Sidhi sebagai jejaring JKBM dan sekarang yang disusul dengan RSUD tahun 2016.

Saran yang bisa kami sampaikan kepada pelayanan RSUD Kabupaten Buleleng terkait pasien jalur JKBM adalah pembenahan pelayanan yang harus mengutamakan kepuasan pasien terhadap pelayanan yang diberikan, dan tidak mendiskriminasi pasien pengguna jalur umum maupun jalur JKBM, karena tingkat kepuasan pasien sangat dibutuhkan untuk meningkatkan prestasi dan citra rumah sakit dimata masyarakat dan pemerintah. JKBM merupakan program yang diterbitkan untuk mensejahterakan rakyat miskin maka dari itu rumah sakit harus mendukung kebijakan tersebut dengan cara memberikan pelayanan terbaik kepada masyarakat.

Selain saran kepada RSUD Buleleng juga saran kami sampaikan kepada pemerintah dimana, pemerintah harus memperhatikan jalannya pelayanan pasien dengan baik, dengan cara mendengarkan keluh-kesah masyarakat terhadap pelayanan pasien di RSUD Buleleng, dengan begitu pemerintah mampu menghimbau kepada RSUD Buleleng untuk membenahi pelayanannya agar mampu mensejahterakan masyarakat miskin sesuai dengan kebijakan yang dikeluarkan.

\section{DAFTAR PUSTAKA}

http://rsud.bulelengkab.go.id/index.php/page/252/Bagian-Umum-dan-SDM http://dinkes.bulelengkab.go.id/index.php/baca-berita/974/3-Rumah-Sakit-Swasta-di-

Buleleng-komit--menyelenggarakan-JKBM http://bali.tribunnews.com/2016/02/04/pasien-jkbm-di-rsud-buleleng-sulit-dapat-kamar http://www.antarabali.com/berita/64731/buleleng-hentikan-jejaring-jkbm-dengan-rs-swasta 